
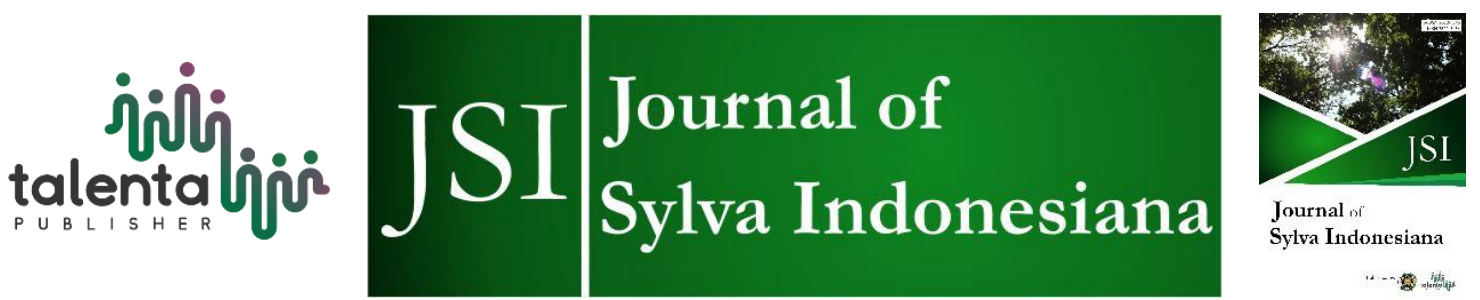

\title{
The Study of Silviculture System for Selective Cutting and Line Planting (TPTJ) and Indonesian Selective Cutting and Planting (TPTI) Application at PT Intracawood Manufacturing Bulungan Regency, North Kalimantan
}

\author{
M. Taufan Tirkaamiana ${ }^{1 *)}$ and Arida Susilowati $^{2}$ \\ ${ }^{1}$ Forestry Study Program, Faculty of Agriculture, Universitas 17 Augustus 1945 Samarinda, East \\ Kalimantan, Indonesia \\ ${ }^{2}$ Faculty of Forestry, Universitas Sumatera Utara, Medan, Indonesia,
}

\begin{abstract}
Selective Cutting and Line Planting (TPTJ) silvicultural systems and Indonesian Selective Cutting and Planting (TPTI) are two of the five silvicultural systems that have been determined by the Ministry of Forestry Regulation No. P.11 / Menhut-II / 2009 juncto P.65 / Menhut-II / 2014 concerning silvicultural systems in the area of timber forest product utilization permits (IUPHHK) in production forests. Three other silvicultural systems based on the regulation are the Gap Logging silviculture system, the Fully Made Rejuvenation System, and the Multi Silviculture System. This study aims to examine the implementation of the TPTJ and TPTI systems in the PT Intracawood Manufacturing (PT Intraca) concession area, Bulungan Regency, North Kalimantan. The methodology of this research is through the approach of growth analysis, comparison of stand increment, observation of environmental conditions, interviews and literature study. Based on the field research, it was found that the diameter increments of Shorea leprosula, Shorea dasyphila, and Shorea parvifolia were greater in the TPTJ system compared to TPTI. However, the TPTI silviculture system at PT Intraca is easier to apply in the field than the TPTJ silviculture system. The TPTJ system has become less effective because planting in the TPTJ system has been carried out by making a 3-meter wide track with a length of approximately $1 \mathrm{~km}$ in a plot and if there is potential for the wood to become ineffective. In the area of PT Intraca, to improve the effectiveness of the TPTJ system a mosaic system is used where the planting path is made only in areas with less potential and representative for planting. The types of plants planted in the TPTJ system are far superior, perspective, and are faster than the types of plants in the TPTI system. Planting/enrichment in the TPTI system is easier because it does not need to make a planting path. Planting with seedlings from the extraction is only a transfer from the growth of tillers from areas with an excessive potential for tillers.
\end{abstract}

Keyword: Increment, Line Planting, Selective Cutting, Superior Species

Received 26 September 2019 | Revised 13 November 2019| Accepted 07 February 2020

\footnotetext{
*Corresponding author at: Forestry Study Program, Faculty of Agriculture, University of Universitas 17 Agustus 1945 Samarinda, Jl. Ir.H. Juanda No.80 Samarinda 75124, Kalimantan Timur, Indonesia, Phone/Fax. +62-541-743390

E-mail address: taufan@untag-smd.ac.id, taufan_ta@yahoo.co.id
} 


\section{Introduction}

In the last decade, the area of tropical rain forests in Indonesia has decreased both in quality and quantity and reduced biodiversity at the species and genetic level [1]. This condition also occurs in Kalimantan, especially in the area of production forest that has experienced a decline not only in terms of its area but also it's potential and productivity, especially in logged-over areas.

Sustainability of tropical forests is one of the agendas that are the basis of the management of production forests in Indonesia. To achieve this goal, mainstreaming sustainable forest management becomes an inseparable part of various forest management programs. At the site level, various regulations were issued to support this objective including the application of three silvicultural systems, namely Indonesian Selective Cutting (TPI), Indonesian Selective Cutting and Planting (TPTI), and Selective Cutting Line Planting (TPTJ). All of these systems are based on selective cutting planting and selective enrichment [2].

The selection and establishment of a silvicultural system are one of the factors that must be considered in sustainable forest management and relates to economic aspects and forest productivity. One thing that must be considered in the selection of silvicultural systems includes knowledge of increment. Silvicultural systems are defined as a series of activities from the stages of rejuvenation, maintenance and yield collection that are systematically designed and practiced directly on a stand throughout its life cycle to ensure the sustainability of timber production or other forest products [3].

According to [4], the basics of selecting a silvicultural system are on the approach: 1) Biodiversity, based on forest type according to the climatic formation., 2) Topography, geography, geology and soil., 3) Soil and water conservation., 4) Technology., and 5) The implementation of a silvicultural system that deviates from existing policies causes the forest management carried out by IUPHHK holders far from the goal of sustainable forest management. This will further reduce forest productivity so that it disrupts the next cutting cycle and the sustainability of forest ecosystems [5]-[6].

There are 5 (five) silvicultural systems that can be applied in IUPHHK areas in production forests, namely Indonesia Selective Cutting and Planting (TPTI), Gap Logging Silvicultur System, Selective Cutting and Line Planting (TPTJ), Clear Cutting with Artificial Regeneration (THPB) and Natural Regeneration, and Multi-Systems Silviculture.

The silvicultural system for uneven age stands was conducted through three logging schemes namely individual, group logging and line logging. Individual selective logging silviculture systems are implemented with TPTI applied to virgin natural forests or logged-over forests, selective cut silviculture systems are implemented with TPTJ applied to logged-over natural forests, whereas for selective silvicultural systems, the group is carried out by logging which is applied to virgin natural forests. 
The silvicultural system commonly implemented by IUPHHK in Kalimantan that manages natural production forests with climatic formations is TPTI with natural regeneration and TPTJ with Intensive Silviculture (SILIN) techniques. While the THPB silvicultural system is applied to logged-over forests whose potential is already very small.

The most basic differences between the TPTI and TPTJ systems are the source/origin of planted seedlings, planting layout, silvicultural techniques, and the target of harvested trees. In the TPTI system, the origin of plant seeds for seedlings is taken from the natural regeneration without a selection of seed types, especially the selection of the increment. Planting is carried out on log blocks that are not rejuvenated, ex-landing, former skid trails, and vacant land. The treatment is more focused on the maintenance of the residual stand, namely the core tree (diameter 20 - 39 $\mathrm{cm}$ in common production forests and $20-49 \mathrm{~cm}$ in limited production forests). The core tree is the main tree which is expected to be harvested in the next cutting rotation because the plants planted in the TPTI system are only enrichment planting, and the silvicultural technique used is selective development technique. Whereas in the TPTJ system the plant seedlings come from vegetative propagation where the source of the seeds is obtained from natural seedlings or fruit (seeds) of target species originating from the parent tree plus with good phenotype. Planted seedlings are selected: superior, prospective and the fastest preparation. Planting locations on the planting lane are flanked by intermediate lanes /dirty lanes. The silvicultural technique applied is an intensive silviculture technique. The plant target for harvested was plant that planted in the planting lane.

The purpose of this study was to determine the effectiveness of the TPTI and TPTJ silvicultural and policy systems and their advantages and disadvantages in forest management in PT Intracawood Manufacturing (hereinafter referred to as PT Intraca) in Bulungan District, North Kalimantan Province.

\section{Research Method}

\subsection{Materials and Research Method}

This research was conducted in the LOA (log over an area), PT Intraca Camp Sekatak's IUPHHK logging area in Bulungan Regency, East Kalimantan Province (Figure 1). The TPTJ Permanent Plot (PUP) research location is located at coordinates $3^{\circ} 15^{\prime} 40.7^{\prime N L}, 117^{\circ} 02^{\prime} 15.8^{\prime \prime}$ EL, while the TPTI PUP research location is located at coordinates $3^{\circ} 23^{\prime} 16.3$ "NL, 116 $54^{\circ} 35.6^{\prime \prime}$ EL. The increment measurement and data collection were carried out at TPTJ PUP locations and TPTI PUP locations. The trees species as the research target are three species of meranti namely Shorea leprosula, Shorea dasyphila, and Shorea parvifolia which are planted in the TPTJ and TPTI systems in the area of PT. Intraca planting year 2012. 


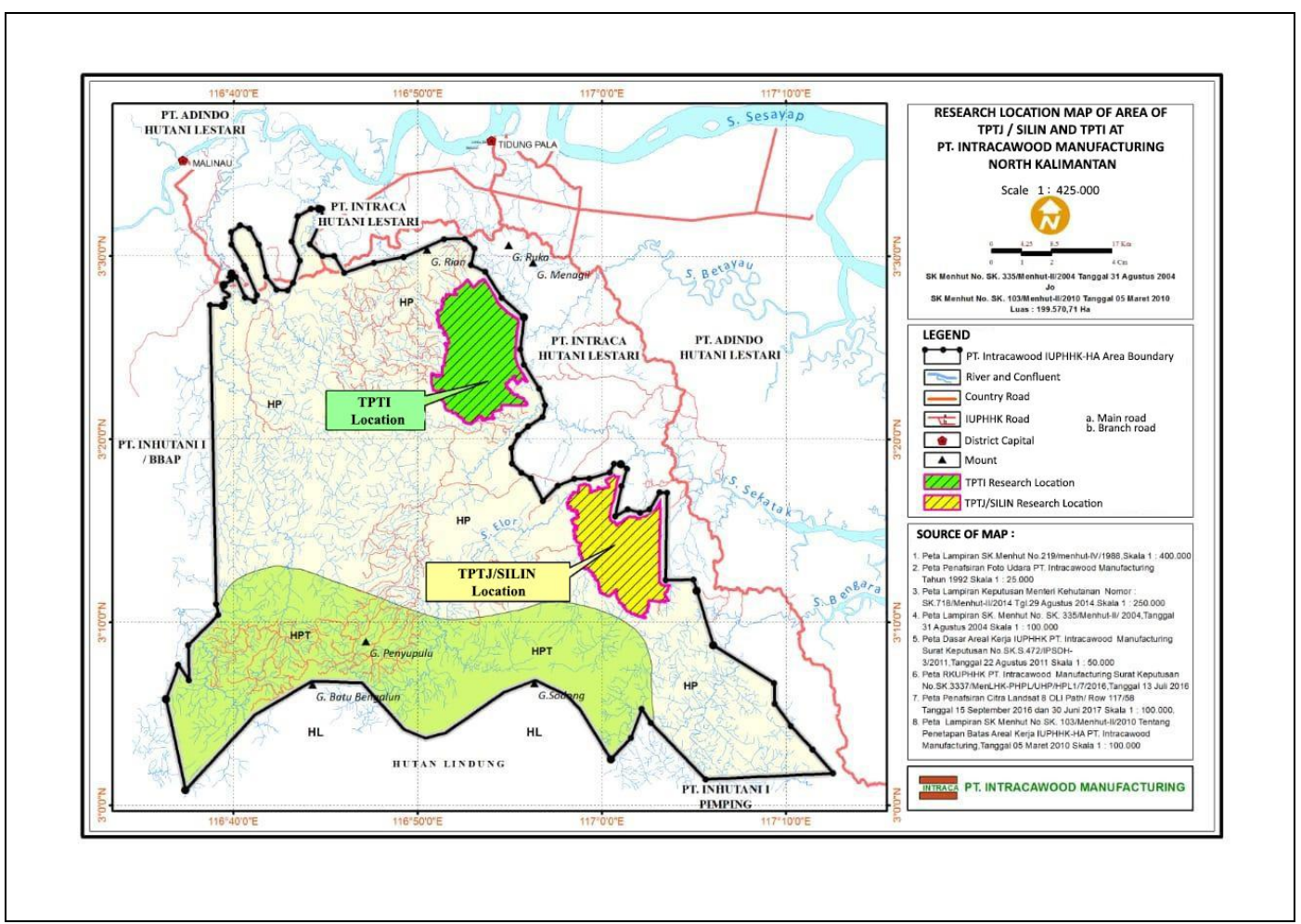

Figure 1 Research location at PT Intraca IUPHHK-HA in Bulungan Regency

To see the position of research location GPS (Global Position System) type Garmin 60Csx and compass were used. Other tools used in this study include clinometer, haga meter, roll meter (50 $\mathrm{m})$, phi band, tally sheet, and digital camera.

\subsection{Research procedures and data analysis}

The study was conducted by collecting data related to stand increment. The measurement of stand increment was carried out on three species those were S. leprosula, S. dasyphila, and S. parvifolia on TPTI PUP and TPTJ PUP. TPTI PUP measuring $200 \mathrm{~m}$ x $200 \mathrm{~m}$ or an area of 4 ha is located in TPKT's 2012 Annual Work Plan RKT block (plot number 3943 (area 114 ha). While TPTJ PUP is made as many as 3 PUP where 1 type of plant occupies 1 PUP, each measuring $100 \mathrm{~m}$ x $100 \mathrm{~m}$ or an area of 1 ha located in the 2012 RKT-TPTJ block plot number 007 covering 110 ha. Planting of TPTI and TPTJ was carried out at Et+ 1 or 1 year after logging (2013 planting year). The position and layout of plants in the TPTJ and TPTI systems can be seen as in Figures 2 and 3. 


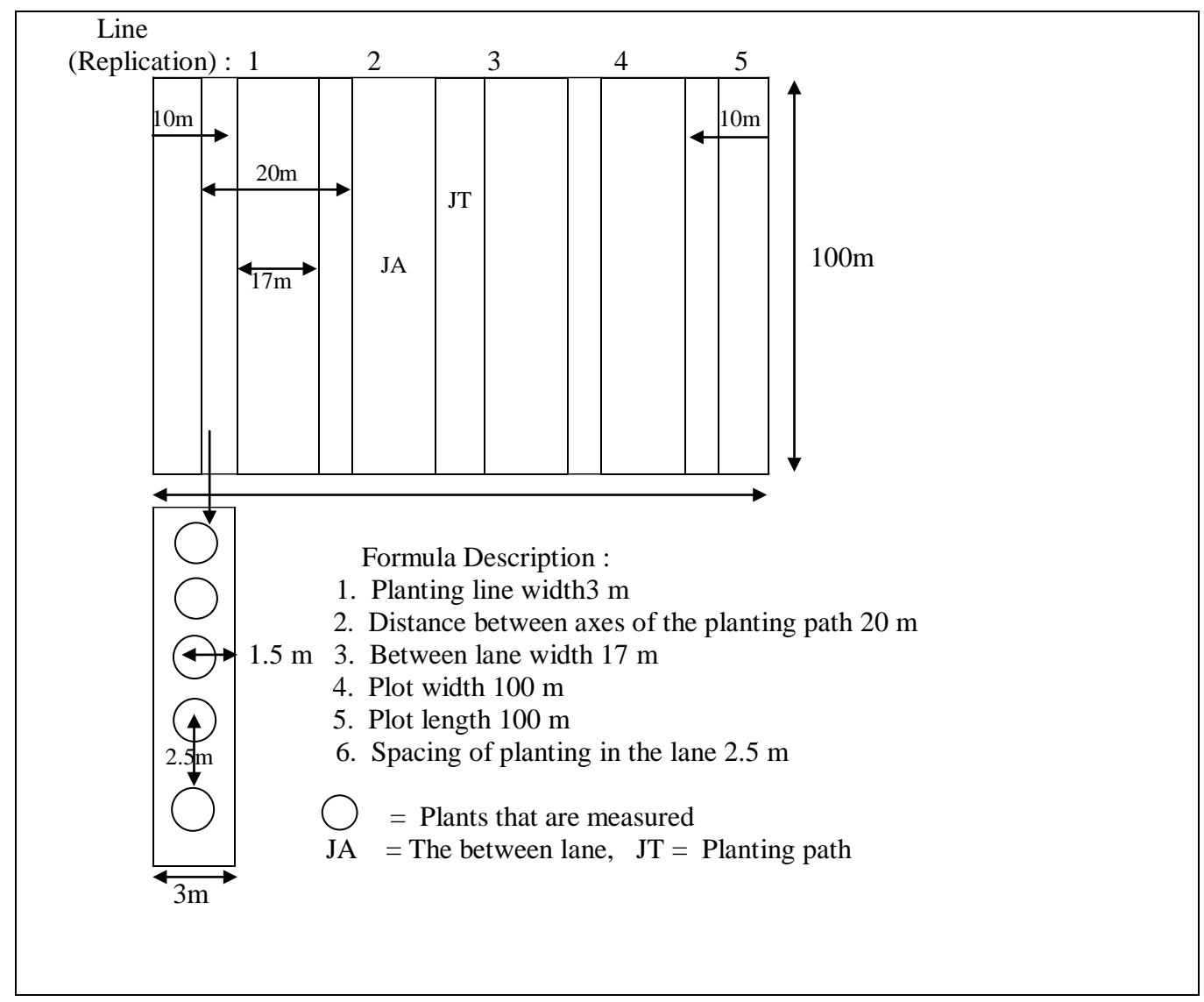

Figure 2 Plant Layout in TPTJ PUP

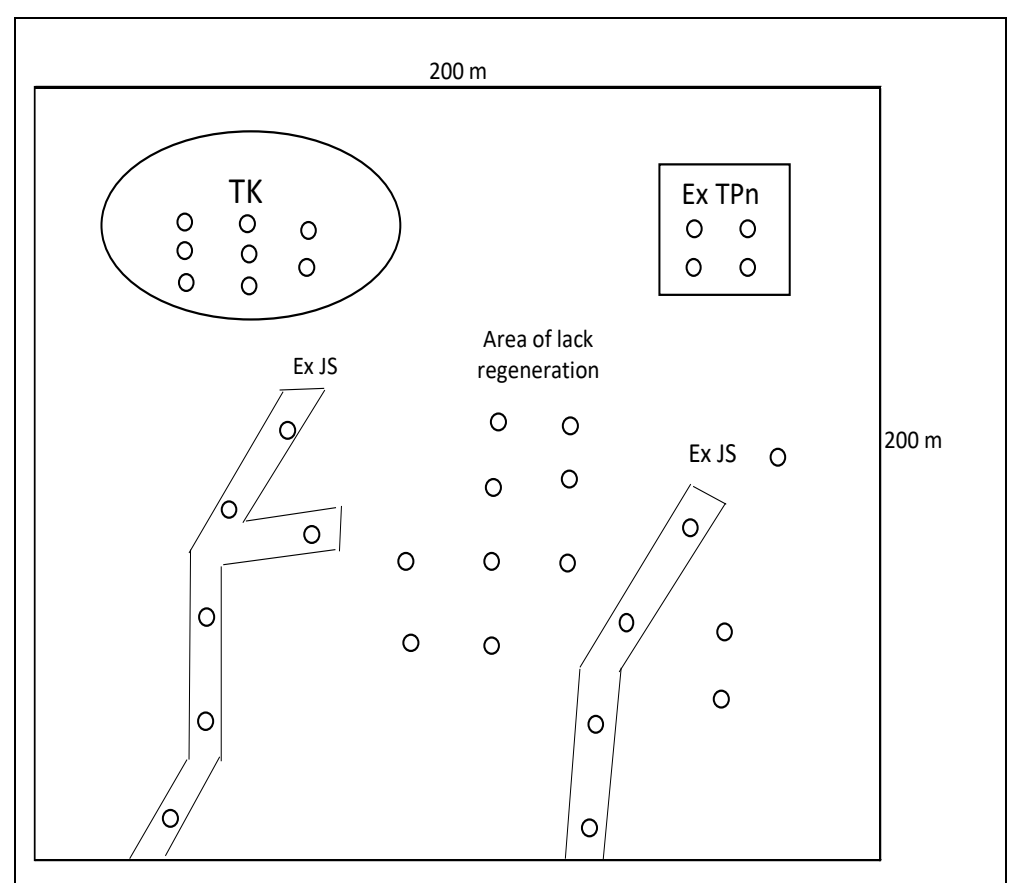

Ket. : $\mathrm{TK}=$ Vacant land, JS = Skid Paths, Planting Distance:

$5 \mathrm{~m} \times 5 \mathrm{~m}$

Figure 3 Plant Layout in TPTI PUP 
While the measured increment stands are diameter increment and measured using the mathematical formula [7] as follows:

$$
\begin{aligned}
\mathrm{CAI} & =Y n-Y(n-1) \\
\mathrm{MAI} & =\frac{Y n-Y o}{T n}
\end{aligned}
$$

where:

CAI $($ Current Annual Increment $)=$ growth increment in one year

MAI (Mean Annual Increment) = average growth for one year

$\mathrm{Yn}=$ tree dimensions at an nth measurement

Yo $=$ tree dimensions at initial measurements

$\mathrm{Tn}=$ nth measurement time

Furthermore, statistical tests to determine the difference in plant diameter increment in TPTJ with stands that remain in TPTI are carried out using statistical analysis (t-test) [8] as follows:

$$
\begin{aligned}
& \mathrm{S}^{2}=\frac{(n 1-1) S 1^{3}+(n 2-1) S 2^{2}}{(n 1-1)+(n 2-1)} \\
& \mathrm{Sd}^{2}=\frac{n 1+n 2}{n 1 n 2} S^{2}
\end{aligned}
$$

Ho: $\mu_{1}=\mu_{2}$

$\mathrm{H} 1: \quad \mu_{1} \neq \mu_{2}$

$$
\mathrm{t}_{\text {hit }}=\frac{x_{1}+x_{2}}{S_{x 1-x 2}}
$$

$\mathrm{t}_{\text {hit }}$ :

$\leq \mathrm{t} \alpha / 2 ;(\mathrm{n} 1+\mathrm{n} 2-2) \rightarrow$ accept Ho $\rightarrow$ there is no significant difference between $\mu 1$ and $\mu 2$

$>\mathrm{t} \alpha / 2 ;(\mathrm{n} 1+\mathrm{n} 2-2) \rightarrow$ accept $\mathrm{H} 1 \rightarrow$ there is a significant difference between $\mu 1$ and $\mu 2$ where :

$\mu 1$ : average diameter of the population ( $\mathrm{cm} /$ year) on TPTJ

$\mu 2$ : average increase in diameter growth in population ( $\mathrm{cm} /$ year) on TPTI

$\mathrm{x}_{1}$ : average increase diameter of the sample $(\mathrm{cm} /$ year) on the plot of TPTJ

$\mathrm{x}_{2}$ : average increase diameter of the sample $(\mathrm{cm} /$ year) on the plot of TPTI 
$\mathrm{S}_{1}$ : variance of TPTJ plot model

$\mathrm{S}_{2}$ : variance of TPTI plot model

$\mathrm{n}_{1}$ : number of TPTJ plot model

$\mathrm{n}_{2}$ : number of TPTI plot model

Meanwhile, to find out the strengths and weaknesses of the TPTI and TPTJ silviculture system some parameter was measured. The observed parameter is growth analysis and comparison of stand stands approach, also through direct observation in the field of stand and environmental conditions, interviews with implementers, responsible parties, and supervisors in the field, library research and regulatory review related to the two silvicultural systems.

\section{Results and Discussion}

\subsection{Increase of Diameter}

The effectiveness of TPTJ and TPTI silvicultural systems implementation in forest management in PT Intraca's work area can be seen from the stand diameter increment measurement. The recapitulation of the measurement results can be seen in Table 1. The current annual diameter increment (CAI) and the annual average diameter increment (MAI) can be seen in Table 1 and Table 2.

Table 1 Current Annual Increment (CAI) and Measurement Annual Increment (MAI) in three species of shorea in TPTJ silvicultural system

\begin{tabular}{|l|c|c|c|c|}
\hline \multirow{2}{*}{ Species } & \multicolumn{3}{|c|}{ TPTJ } & \multirow{2}{*}{ MAI } \\
\cline { 2 - 4 } & \multicolumn{3}{|c|}{ CAI (cm/year) } \\
\cline { 2 - 4 } & $\begin{array}{c}\text { Increase to-1 } \\
(2014 / 2015)\end{array}$ & $\begin{array}{l}\text { Increase to-2 } \\
(2015 / 2016)\end{array}$ & $\begin{array}{l}\text { Increase to-3 } \\
(2016 / 2017)\end{array}$ & \\
\hline Shorea leprosula & 2.10 & 1.94 & 1.60 & 1.88 \\
Shorea dasyphila & 1.75 & 1.82 & 1.47 & 1.68 \\
Shorea parvifolia & 2.18 & 1.85 & 1.73 & 1.92 \\
\hline Average & 2.01 & 1.87 & 1.60 & 1.83 \\
\hline
\end{tabular}

Table 2 Current Annual Increment (CAI) and Measurement Annual Increment (MAI) in three species of shorea in TPTI silvicultural system

\begin{tabular}{|l|c|c|c|c|}
\hline \multirow{2}{*}{\multicolumn{1}{c|}{ Species }} & \multicolumn{3}{|c|}{ TPTI } & \multirow{2}{*}{ MAI } \\
\cline { 2 - 4 } & \multicolumn{3}{|c|}{ CAI (cm/year) } \\
\cline { 2 - 4 } & $\begin{array}{r}\text { Increase to-1 } \\
(2014 / 2015)\end{array}$ & $\begin{array}{c}\text { Increase to-2 } \\
(2015 / 2016)\end{array}$ & $\begin{array}{c}\text { Increase to-3 } \\
(2016 / 2017)\end{array}$ & \\
\hline Shorea leprosula & 0.96 & 0.93 & 0.78 & 0.89 \\
Shorea dasyphila & 0.58 & 0.82 & 0.88 & 0.76 \\
Shorea parvifolia & 0.87 & 1.04 & 0.91 & 0.94 \\
\hline Average & 0.80 & 0.93 & 0.86 & 0.86 \\
\hline
\end{tabular}


Based on Table 1, it can be seen that during the observation period, the largest diameter increment occurred in increment 1 , ie from the age of 1 year to 2 years and increment to 2 , from age 2 years to 3 years in both S. leprosula, S. dasyphila and S. parvifolia, this is likely due to the early years the company was still intensively carrying out complete and intensive plant maintenance. But in the third increment from the age of 3 years to 4 years the maintenance is not as complete and intensive as the previous year.

Whereas in Table 2 we can see the diameter increment in the TPTI system for the three types at the age of 3 years to 4 years. There was no decrease. This was due to maintenance activities, although not as intense as in the TPTJ system, but relatively the same every year, besides the location of the plants scattered among the stands stay so that growth is influenced by the existing shade conditions.

Tables 1 and 2 produce a comparison of the recapitulation of the average diameter increments of the three types in the TPTJ and TPTI systems as in Table 3.

Table 3 Comparison of average diameter recapitulation $(\mathrm{cm})$ in the year for three meranti species in TPTJ and TPTI silvicultural systems

\begin{tabular}{lcc}
\hline \multicolumn{1}{c}{ Species } & $\begin{array}{c}\text { Diameter Increment } \\
(\mathrm{cm} / \text { year}) \text { TPTJ }\end{array}$ & TPTI \\
\hline Shorea leprosula & 1.88 & 0.89 \\
Shorea dasyphila & 1.68 & 0.76 \\
Shorea parvifolia & 1.92 & 0.94 \\
\hline Average & 1.83 & 0.86 \\
\hline
\end{tabular}

The results of statistical data analysis to compare TPTJ diameter increments with TPTI by using the t-test showed Shorea leprosula and Shorea parvifolia were significantly different, whereas for Shorea dasyphila not significantly different. This can be indicated that the growth and diameter increment of S. leprosula and S. parvifolia as plant species that have a better level of suitability of growing land in logged areas in the TPTJ system compared to the TPTI system or compared to Shorea dasyphila both in the TPTJ and TPTI systems. In other words for the case of Shorea leprosula and Shorea parvifolia because the results of the comparison of two intermediate values of the TPTI and TPTJ silvicultural systems differ significantly, this means that planting with the TPTJ system is the best way to plant in logged-over areas.

The results of this study are also strengthened by the research on meranti diameter in the TPTI and TPTJ systems in PT Suka Jaya Makmur, Ketapang Barat Regency, West Kalimantan. From the results of comparing the two intermediate values of the TPTI and TPTJ silvicultural systems, this significant difference means that planting with the TPTJ system is the best way to plant in logged-over areas [9]. 
In the TPTJ system planting is carried out in the planting lane, therefore the growth and diameter increment of S. leprosula, S. dasyphila, and S. parvifolia are 5 years greater than in the TPTI system. This shows that for the three species of meranti, the response of a 3-meter wide opening of planting track has a significant influence on growth and diameter increment. This also shows that intensive maintenance of the TPTJ system will have a very important influence on the growth and diameter of the plant.

In the planting path of TPTJ system, the increment of plant diameter achieved is greater than in the TPTI, this is due to the distance of planting or planting paths resulting in fewer trees and competition for nutrient and light requirements for plants is relatively smaller, to increase growth.

Wider spacing gives better growth in diameter and height than narrower spacing [10]. This is because the relationship of receiving light intensity to the forest floor will affect the photosynthesis process in trees. Optimum light intensity reception on the leaves will accelerate the rate of transpiration, opening the stomata, thus affecting the process of photosynthesis. The maximum photosynthesis process will accelerate the growth of plant diameter and height. Opening the canopy closure is essential for successful regeneration. Shade studies show that Dipterocarpaceae requires a greater amount of light radiation than direct light radiation [11][12].

The difference in diameter increment between TPTJ and TPTI is not only due to the factors mentioned above but also due to differences in the treatment of silvicultural systems and the environment around plants as well as genetic factors. The plant species planted in the TPTJ system are the result of superior seeds that have been selected and are better compared to the TPTI system where the seeds are natural stands.

This factor is in line with the opinion that tree growth is largely determined by the interaction between the three factors, namely heredity, environment and silvicultural techniques [13]. Whereas [14] states that several factor that influence of increment stand are silviculture, species, and quality of the place to grow. Furthermore [15] states that the increment of trees varies according to tree species. In general, the variation of shade in the planting path and the uniformity of age of the plant seedlings used also greatly influences the development of plant growth [16]. Some companies in Indonesia also still use seeds from around the location to be used in silvicultural systems. Even in Central Kalimantan, the Shorea leprosula plant can be used as a model plant in the SILIN TPTJ system [17]-[18]. Intensive plant maintenance in the form of vertical and horizontal cutting should routinely be continued until the plants are 3 years old to obtain maximum results [19]. 


\subsection{Strengths, Weaknesses / Constraints of TPTJ and TPTI}

Methodology to quantify the strengths and weaknesses of the TPTJ and TPTI systems for technical and ecological aspects through an approach to the calculation of the stand increment and its comparisons, observation of juvenile and standing conditions and the environment, interviews with implementers and supervisors in the field. While the economic and social aspects in addition to observations in the field also through approaches: interviews with the person in charge and supervisors in the field, and literature study, specifically for the social aspects of interviews conducted also on the surrounding community.

From the results of the study of policy concepts and observations in the field in applying the TPTJ and TPTI silvicultural systems at PT Intraca with the methodology according to the aspects being compared, the advantages and disadvantages of the two systems can be seen as shown in Table 4.

Table 4 Strengths and Weaknesses of the TPTJ and TPTI systems

\begin{tabular}{|c|c|c|c|c|}
\hline \multirow{2}{*}{ Aspect } & \multicolumn{2}{|c|}{ TPTJ } & \multicolumn{2}{|c|}{ TPTI } \\
\hline & Strength & Weakness & Strength & Weakness \\
\hline $\begin{array}{l}\text { A. } \\
\text { Technical } \\
\text { and } \\
\text { Ecology }\end{array}$ & $\begin{array}{l}\text { 1. There are } \\
\text { superior species } \\
\text { and target } \\
\text { species on the } \\
\text { planting track } \\
\text { 2. Growth and } \\
\text { plant increment } \\
\text { is fast } \\
\text { 3. Less } \\
\text { competition for } \\
\text { nutrients and } \\
\text { sunlight } \\
\text { 4. Rejuvenation of } \\
\text { semi tolerant } \\
\text { species is easier } \\
\text { to grow } \\
\text { 5. Planting is } \\
\text { easier because it } \\
\text { follows the } \\
\text { planting path } \\
\text { 6. Planning for } \\
\text { regeneration is } \\
\text { easier } \\
\text { 7. Supervision on } \\
\text { rejuvenation is } \\
\text { easier }\end{array}$ & $\begin{array}{l}\text { 1. Species } \\
\text { diversity is } \\
\text { reduce } \\
\text { 2. Vertical canopy } \\
\text { closure is } \\
\text { reduce } \\
\text { 3. Rejuvenation } \\
\text { of tolerant } \\
\text { species is } \\
\text { difficult to } \\
\text { grow well } \\
\text { 4. Need intensive } \\
\text { maintain } \\
\text { 5. Reduce pest } \\
\text { and diseases } \\
\text { protection } \\
\text { 6. Need to make a } \\
\text { planting path } \\
\text { 7. Structure, } \\
\text { composition } \\
\text { and stand } \\
\text { density are } \\
\text { reduced } \\
\text { 8. Disturb animal } \\
\text { habitat }\end{array}$ & $\begin{array}{l}\text { 1. Maintain the } \\
\text { diversity of } \\
\text { species } \\
\text { 2. Vertical } \\
\text { canopy closure } \\
\text { occurs } \\
\text { 3. Rejuvenation } \\
\text { of tolerant } \\
\text { species can } \\
\text { grow well } \\
\text { 4. Protection of } \\
\text { pests and } \\
\text { diseases is } \\
\text { maintained } \\
\text { 5. No need for } \\
\text { intensive } \\
\text { maintain } \\
\text { 6. Structure, } \\
\text { composition, } \\
\text { and density of } \\
\text { stands are } \\
\text { more awake } \\
\text { 7. Animal habitat } \\
\text { is maintained }\end{array}$ & $\begin{array}{l}\text { 1. The superior } \\
\text { species depends } \\
\text { on the natural } \\
\text { stand available } \\
\text { 2. Increment } \\
\text { growth is slow } \\
\text { 3. Competition for } \\
\text { nutrients and } \\
\text { sunlight is } \\
\text { tighter } \\
\text { 4. Rejuvenation or } \\
\text { enrichment of } \\
\text { species spread } \\
\text { over the area } \\
\text { 5. Planning for } \\
\text { regeneration is } \\
\text { more difficult } \\
\text { 6. Supervision of } \\
\text { rejuvenation is } \\
\text { more difficult }\end{array}$ \\
\hline A. Economy & $\begin{array}{l}\text { 1. The type of } \\
\text { wood planted } \\
\text { and harvested at } \\
\text { the end of the } \\
\text { cycle can be } \\
\text { adjusted } \\
\text { 2. The value of } \\
\text { wood harvested }\end{array}$ & $\begin{array}{l}\text { 1. The cost of } \\
\text { making a large } \\
\text { planting line } \\
\text { 2. The cost of } \\
\text { regeneration is } \\
\text { more expensive } \\
\text { 3. Investment } \\
\text { costs for }\end{array}$ & 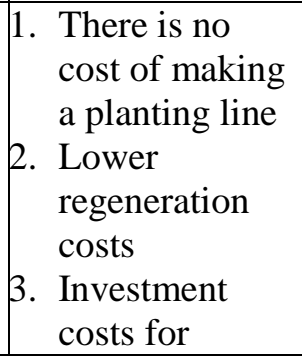 & $\begin{array}{l}\text { 1. Types of wood } \\
\text { harvested at the } \\
\text { end of the cycle } \\
\text { are limited } \\
\text { 2. The value of } \\
\text { wood harvested } \\
\text { is relatively } \\
\text { cheaper / }\end{array}$ \\
\hline
\end{tabular}




\begin{tabular}{|c|c|c|c|c|}
\hline & $\begin{array}{l}\text { is predicted to } \\
\text { be more } \\
\text { expensive } \\
\text { 3. The cost of field } \\
\text { supervision is } \\
\text { cheaper }\end{array}$ & $\begin{array}{l}\text { infrastructure } \\
\text { are more } \\
\text { expensive }\end{array}$ & $\begin{array}{l}\text { infrastructure } \\
\text { are cheaper }\end{array}$ & $\begin{array}{l}\text { stagnant } \\
\text { 3. The cost of field } \\
\text { supervision is } \\
\text { more expensive }\end{array}$ \\
\hline B. Social & $\begin{array}{l}\text { 1. Open more job } \\
\text { field } \\
\text { 2. The image of } \\
\text { planting } \\
\text { increases } \\
\text { 3. Community } \\
\text { disturbances/pre } \\
\text { ssure on forest } \\
\text { decreases } \\
\text { 4. Minimize illegal } \\
\text { logging }\end{array}$ & $\begin{array}{l}\text { 1. More } \\
\text { vulnerable to } \\
\text { fire hazards } \\
\text { 2. Communities } \\
\text { are more } \\
\text { skeptical / } \\
\text { sustainability } \\
\text { because of LC } \\
\text { in the planting } \\
\text { path } \\
\text { 3. Disturbance of } \\
\text { protected flora } \\
\text { and fauna is } \\
\text { increasing }\end{array}$ & $\begin{array}{l}\text { 1. The image of } \\
\text { sustainable } \\
\text { forest } \\
\text { management } \\
\text { for the } \\
\text { community is } \\
\text { still } \\
\text { maintained } \\
\text { because there } \\
\text { is no Land } \\
\text { Clearing (LC) } \\
\text { activity } \\
\text { 2. Disturbance to } \\
\text { protected flora } \\
\text { and fauna is } \\
\text { still lacking }\end{array}$ & $\begin{array}{l}\text { 1. Job field } \\
\text { absorption is } \\
\text { lacking } \\
\text { 2. Image of } \\
\text { planting is } \\
\text { lacking } \\
\text { 3. } \text { Community } \\
\text { disturbances/pre } \\
\text { ssure on forests } \\
\text { decreases } \\
\text { 4. Illegal logging is } \\
\text { still difficult to } \\
\text { minimize }\end{array}$ \\
\hline
\end{tabular}

The results of the comparison of plant increment showed that the increment of the three species planted in the TPTJ system was greater than in the TPTI system. T-test results of the three types, two types namely Shorea leprosula and Shorea parvifolia that were planted in the TPTJ and TPTI systems were significantly different. This is because the seeds planted in the TPTJ system come from seedlings that have been selected and the treatment is applied both at the stage of seedling/nursery procurement, planting, and maintenance using intensive silvicultural techniques. So that the technical and ecological aspects of the TPTJ system have advantages, especially better plant growth because in addition to superior seeds also environmental conditions that support growth both at the bottom (lack of nutrient competition) and at the top with the opening of a $3 \mathrm{~m}$ wide planting path causes reception of optimal light intensity by plants. Whereas in the TPTI system there is no planting path opening using land clearing as wide as $3 \mathrm{~m}$. Therefore in the TPTI system species diversity, structure, composition and stand density are better maintained. But in the TPTI block, the layout of the plantations is scattered in several locations where there is no regeneration, so that supervision of the plants is more difficult than in the TPTJ block where the location of the plants is regularly in the planting path.

The results of field observations and interviews with TPTJ implementers, often found stands especially macaranga spp trees that are on the edge of the path between the planting lane, canopy cover the plants in the planting lane. So that plant maintenance needs to be carried out more frequently or widen the planting path from $3 \mathrm{~m}$ to $4 \mathrm{~m}$ to $6 \mathrm{~m}$. This resulted in increased plant maintenance costs in the TPTJ system. 
The results of interviews with the person in charge of PT Intraca's TPTI activities and based on the RKAP document obtained the costs of TPTI activities outside of the Work Area Arrangement (PAK), Pre-felling Inventory (ITSP), Forest Area Opening (PWH) and Harvesting or forest development fees of Rp. 3,277. 243 per ha, if the forest potential in PT Intraca averages around $40 \mathrm{~m} 3$ per ha, then the TPTI cost per $\mathrm{m} 3$ is Rp. 82,000.

While direct investment costs for TPTJ activities include seed procurement activities, land preparation, planting, and maintenance in PT Intraca totaling Rp. 642,026, per ha while in PT BFI the total cost of TPTJ is Rp. 7,311,005 per ha [20]. Therefore, from an economic aspect, the TPTI system's shortcomings are the large costs incurred. Even though the trees to be harvested are superior and prospective species, so the timber is predicted to have a high selling price, but the harvesters must wait for 25 years (rotation of the TPTJ cutting system) so that the cumulative costs from year to year become even greater.

Silvicultural techniques applied to the TPTJ system are intensive silvicultural techniques both in seed procurement, planting, and maintenance activities that require more labor than TPTI activities that apply selective silviculture techniques that are more focused on the maintenance of residual stands.

The advantages of the TPTJ system from the social aspect, besides the absorption of more labor than the TPTI system also the lack of pressure or disturbance to the forest due to the planting activities that are visible in the planting path. Whereas the TPTI planting activity is only enrichment and is more focused on maintaining the residual stand so that the assessment of the surrounding community on TPTI activities such as no planting or lack of an image of planting. This has resulted in parties who are more willing to claim forest areas and even carry out illegal logging on TPTI blocks compared to TPTJ blocks with more plants.

Overall, the structure of the TPTJ silvicultural system concept and policy is superior both in technical, economic and social aspects compared to TPTI. The superior species that have been selected and the faster stand increment will get a shorter cutting cycle with a more expensive stand value. Also, stands in the intermediate path, although they are residual stands, see that the existing potential can still expected to be harvested at the end of the cycle. While the ecological aspect is thought to be TPTI slightly superior to TPTJ but there is still a path between those that have the potential and species diversity per hectare more or less the same as in TPTI, so this helps the ecological aspects of the TPTJ system.

There are indications that the structure of the forest will never be normal because the time is when the diameter of the trees making up the stand reaches $50 \mathrm{~cm}$ then it will be cut down in total. Obligation to cut trees at the end of the cycle is a must because the main hope is that the stands are built. If at the end of the cycle, the intermediate path is also cut down, the production 
will increase sharply, but the structure of the forest after logging is still questioned as to its form and normality [21].

The obstacle faced in the implementation of TPTJ system is the high costs for procurement of seedlings, planting, and maintenance to burden the company's cash flow. While the technical obstacle in the field is having to make a planting line / straight line as wide as 3 meters and as long as approximately $1 \mathrm{~km}$ in one plot, so it is not effective if there is still potential for timber in the planting path, heavy or unrepresentative fields are found to be planted. Therefore, the rejuvenation of the planting lane at PT Intraca is made with a mosaic system, which is making the planting lane on gaps that have little or no regeneration. Another obstacle faced is the rapid closure of the canopy stands in the lane between the edges covering the planting lane, thereby increasing maintenance costs.

\section{Conclusion}

The diameter of Shorea leprosula, Shorea dasyphila, and Shorea parvifolia are greater in the TPTJ system than in TPTI. The TPTI silviculture system at PT Intraca is easier to implement in the field than the TPTJ silviculture system. This is because in the TPTJ system planting uses a track system, so it is not effective if there is still potential for timber in the planting path. In PT Intraca's area to make planting effective in the TPTJ system, a mosaic system is used where plant paths are made only in areas with less potential and are representative for planting. While planting/enrichment in the TPTI system is easier to implement because there is no need to make a planting path. Overall, in the structure of the TPTJ silvicultural system concept and policy, it is superior to TPTI. The obstacle faced in the TPTJ system is the high cost of regeneration.

\section{REFERENCES}

[1] S. Widyatno, Purnomo, Soekotjo, M. Na'iem, S. Hardiwinoto, "Growth of selected Shorea spp. in secondary tropical rainforests: the effect of silvicultural treatments to improve the quality of growth Shorea spp.," J Penelitian Hutan Konservasi Alam, vol. 8, no. 4, pp. 373-383. 2013.

[2] M. Na'iem, Widiyatmo, M. Zaky Al-Fauzi, "Progeny Test of Shorea leprosula as Key Point To Increase Productivity of Secondary Forest In PT Balik Papan Forest Industries, East Kalimantan, Indonesia," Environmental Sciences, 2013.

[3] Forestry Ministry, Peraturan Kehutanan Nomor: P.65/Menhut-II/2014 tentang perubahan atas PeraturanMenteri Kehutanan Nomor: P.11/Menhut-II/2009 Tentang Sistem Silvikultur dalam Areal Izin Usaha Pemanfaatan Hasil Hutan Kayu pada Hutan Produksi, Jakarta, 2014.

[4] Kementerian Presiden Republik Indonesia, Peraturan Pemerinta RI Nomor: 6 Tahun 2007 tentang Tata Hutan dan Penyusunan Rencana Pengelolaan Hutan, serta Pemanfaatan Hutan, Jakarta, 2007.

[5] Soekotjo, Teknik silvikultur intensif, Gadjah Mada University Press, Yogyakarta. 2009.

[6] G. Hardiansyah, "Analisis pertumbuhan tanaman meranti pada sistem tebang pilih tanam jalur (TPTJ)," Vokasi, vol. 8, no. 3, pp. 165-171. 2012.

[7] R. Kuswandi, "Formulasi dinamika pertumbuhan hutan alam lahan kering di Papua," Jurnal Penelitian Balai Penelitian Kehutanan Manokwari, Manokwari, 2013.

[8] Steel and Torrie, Prinsip dan Prosedur Statistika, Gramedia, Jakarta, 1980. 
[9] W.O. Selfiany, A. Muin, Iskandar, "Diameter increment of Shorea at Silvicultural System of Indonesian Selective Logging and Plantation (TPTI) and Selective Logging and Line Planting (TPTJ) in the area of IUPHHK-HA PT. Suka Jaya Makmur Ketapang district west borneo)," J Hutan Lestari, Pontianak, 2017.

[10] D. Lepe and M. Noor, "Uji Coba Jenis dan Jarak Tanam Tiga Jenis Meranti," Jurnal Penelitian Hutan Tropika Samarinda, Wanatrop, 1992.

[11] S. Sasaki, "Growth and storage of bare-root planting stock of dipterocarps with special reference to Shorea talura," Malaysian Forester, vol. 43, pp. 144-160. 1980.

[12] P.S. Ashton, "Flora Indo-Malayana," Seri I., vol. 9, no. 2, pp. 237-552. 1982.

[13] P.J. Kramer and Th.T. Kozlowski, Physiology of Trees, McGraw-HillBook Company, New York, 1960.

[14] A.B. Lai, Silviculture system and forest management, Jugal Kishore \& Co, Indi, 1960.

[15] H. Siti, Tinjauan konseptual model pertumbuhan dan hasil tegakan hutan, USU Press, Sumatera Utara, 2004.

[16] Widiyatno, Soekotjo, M. Naiem, S. Hardiwinoto and S. Purnomo, "Pertumbuhan meranti (Shorea spp.) pada sistem tebang pilih tanam jalur dengan teknik silvikultur intensif (TPTJ-SILIN)," Jurnal Penelitian Hutan dan Konservasi Alam, vol. 8, no. 4, pp. 373-383. 2011.

[17] Wahyudi, A. Indrawan, I. Mansyur, and P. Pamungkas. "Tebang Pilih Tanam Jalur: Pemodelan pertumbuhan tanaman meranti pada jalur tanam," Jurnal Ilmu Pertanian Indonesia, vol. 15, no. 1, pp. 34-40. 2010.

[18] Wahyudi and S. Panjaitan. "Model pertumbuhan dan hasil tanaman Shorea leprosula pada sistem tebang pilih tanam jalur teknik silin," Jurnal Penelitian Dipterokarpa, vol. 5, no. 2, pp. 37-46. 2011.

[19] P. Pamoengkas and R. Prasetia. "Pertumbuhan meranti merah (Shorea leprosula Miq) dalam sistem tebang pilih tanam jalur di areal IUPHHK-HA PT. SARPATIM, Kalimantan Tengah,” Jurnal Silvikultur Tropika, vol. 5, no. 3, pp. 174- 180. 2014.

[20] M. Na'iem and E. Faridah, In A. Rimbawanto (Ed), Model in Intensive Enrichment Plating (TPTII), Silviculture System Of 93 Evaluation of Silvicultural System Application Activities. Karmilasanti; Tien Wahyuni, Indonesia's Dipterocarps Forest Management: A Lesson Learned, Faculty of Forestry GMU and International Tropical Timber Organization, Indonesia, pp. 25-36, 2006.

[21] B.H. Sihombing, "Overview of Concepts and Implementation of Silvicultural Systems," Jurnal AGRIFOR, vol. 14, no. 1. 2015. 